\title{
ANALISIS FITUR DALAM APLIKASI INSTAGRAM SEBAGAI MEDIA PEMBELAJARAN ONLINE MATA PELAJARAN BIOLOGI UNTUK SISWA SEKOLAH MENENGAH ATAS
}

\author{
Ahmad Veygid ${ }^{1}$, Sandy M. Aziz ${ }^{1}$, Wildan Said S.R. ${ }^{1}$ \\ ${ }^{1}$ Institut Agama Islam Negeri Jember, Jl. Mataram No. 1 Mangli, Jember \\ 68136, Jawa Timur, Indonesia \\ E-mail: avveygid11@gmail.com
}

\begin{abstract}
Today precisely in mid-2020 the world is horrified by the Corona Virus Disease-19 (Covid-19) outbreak that forces all elements of society to Work Form Home (WFH), this is very difficult especially for educators because of face-to-face learning is removed, and it forces educators to use the information technology that is currently developing to support online learning. However, in its implementation there are obstacles because some applications such as google classroom, edmodo, zoom are very difficult to use and the class becomes less interactive, which underlies researchers to conduct research because the Instagram application is very user friendly and very familiar to be used by millennials and the use of the Instagram app as a biology learning media can make the class more interactive because there are live features that make it easier for teachers and students to interact. This research uses a mix method using a Likert scale ranging from 1-5 to the data processing. The data obtained came from a high school student questionnaire majoring in Natural Sciences. Based on research conducted by researchers and the results of the Instagram application questionnaire is very suitable as a medium of online or online biology learning this is because the Instagram application is very easy to use and is a familiar application among millennials, especially high school students.
\end{abstract}

Keywords: E- Learning, Instagram, COVID-19

\begin{abstract}
Abstrak: Dewasa ini tepatnya pada pertengahan tahun 2020 dunia dihebohkan dengan wabah Corona Virus Disease-19 (Covid-19) yang memaksa semua elemen masyarakat untuk bekerja dari rumah atau Work Form Home (WFH), hal ini sangat menyulitkan terlebih lagi bagi tenaga pendidik karena pembelajaran tatap muka ditiadakan, dan memaksa tenaga pendidik untuk menggunakan teknologi infomasi yang berkembang saat ini untuk menunjang pembelajaran secara online. Akan tetapi dalam pelaksanaanya terdapat kendala karena beberapa aplikasi seperti google classroom, edmodo, zoom sangat sukar digunakan dan kelas menjadi kurang interaktif, hal ini yang mendasari peneliti melakukan penelitian karena aplikasi Instagram sangat user friendly dan sangat familiar digunakan oleh generasi milenial dan penggunaan apikasi Instagram sebagai media pembelajaran biologi dapat menjadikan kelas lebih interaktif karena terdapat fitur live yang memudahkan guru dan siswa untuk berinteraksi. Penelitian ini menggunakan metode mix dengan menggunakan skala likert rentang 1-5 pada proses pengolahan data. Data yang diperoleh berasal dari kuesioner siswa SMA jurusan IPA. Berdasarkan penelitan yang dilakukan peneliti dan hasil dari kuesioner aplikasi Instagram sangat cocok dijadikan media pembelajaran biologi secara online atau daring hal ini dikarenakan aplikasi Instagram sangat mudah untuk digunakan dan merupakan aplikasi yang familiar dikalangan generasi milenial terutama siswa SMA.
\end{abstract}

Kata kunci: Pembelajaran daring, Instagram, COVID-19

Pada pertengahan tahun 2020, dunia dikejutkan dengan mewabahnya sebuah virus 
yang sangat berbahaya yaitu Virus Corona (COVID-19). Sebelumnya pada tanggal 11 Maret 2020, WHO telah menetapkan COVID-19 sebagai Pandemi yang persebarannya secara geografis telah mencakup 114 negara di dunia. Awal kemunculannya adalah di Kota Wuhan, Provinsi Hubei, China dan menyebar ke berbagai belahan dunia temasuk juga Indonesia. Menyebarnya virus tersebut sangat memberikan dampak yang sangat nyata di berbagai bidang kehidupan masyarakat khususnya pendidikan.

Kondisi pendidikan di Indonesia sendiri sangat terganggu sehingga pemangku kebijakan harus melakukan perubahan kebijakan dan mengatur kembali tatanan pendidikan di Indonesia. Salah satunya adalah diterbitkannya SE (Surat Edaran) oleh Mendikbud Nadiem Anwar Makarim mengenai Pelaksanaan Kebijakan Pendidikan dalam Masa Darurat Penyebaran Corona Virus Disease (COVID-19). Dimana beberapa isi pada SE tersebut adalah mengenai pembatalan Ujian Nasional untuk masing-masing tingkatan akhir sekolah, aturan pelaksanaan Ujian Sekolah dan kenaikan kelas, penerimaan peserta didik baru serta aturan belajar dari rumah selama masa pandemi.

Pada pelaksanaannya, aktivitas belajar dirumah oleh semua tingkatan pendidikan di Indonesia memanfaatkan berbagai media pembelajaran online atau yang biasa disebut dengan $e$ learning. Menurut Widanarko dalam Nasution ( 2011) e-learning sendiri merupakan kegiatan atau proses pembelajaran, dimana kegiatan atau proses pembelajaran tersebut memanfaatkan teknologi informasi dan komunikasi (TIK) secara sistematis atau terstruktur dan dengan mengintegrasikan seluruh komponen pembelajaran. Macam-macam contoh dari e-learning adalah Edmodo, Moodle, Google Classroom, dan media lainnya yang masing-masing mempunyai keunggulan dan kekurangan dalam mendukung proses pembelajaran online dirumah.

Oemar Hamalik mendefinisikan media pembelajaran sebagai Alat, metode, dan teknik yang digunakan dalam rangka lebih mengefektifkan komunikasi dan interaksi antara guru dan siswa dalam proses pendidikan dan pengajaran di sekolah (Hamalik, 1989).

Efektivitas proses belajar mengajar (pembelajaran) sangat dipengaruhi oleh faktor metode dan media pembelajaran yang digunakan. Keduanya saling berkaitan, di mana pemilihan metode tertentu akan berpengaruh terhadap jenis media yang akan digunakan, dengan kata lain bahwa harus ada kesesuaian di antara keduanya untuk mewujudkan tujuan pembelajaran. Walaupun ada hal-hal lain yang juga perlu diperhatikan dalam pemilihan media, seperti: konteks pembelajaran, karakteristik pembelajar, dan tugas atau respons yang diharapkan dari pembelajar (Arsyad, 1997).

Beberapa media yang sudah sering digunakan, mempunyai kekurangan baik dari segi 
penggunaan dan tampilan yang monoton. Sehingga banyak pendidik yang melakukan inovasi dengan memanfaatkan media sosial yang sangat menarik dan mudah dalam pengoperasiannya untuk dijadikan sebagai media pembelajaran online. Salah satu aplikasi media sosial tersebut adalah Instagram dimana Instagram dapat menghubungkan guru atau pendidik untuk selalu terhubung dengan peserta didik (Zhang, 2013).

Perubahan tata kelola kebijakan pendidikan di era pandemi COVID-19, ditandai dengan beralihnya pembelajaran tatap muka di ruang kelas (konvesional) menuju pembelajaran daring (online). Kondisi ini memungkinkan siswa dan siswi belajar secara penuh di rumah masing-masing dengan fasilitas penunjang seperti gawai dan akses internet untuk mengakses ruang kelas virtual yang telah disediakan oleh guru. Proses interaksi antara guru dan peserta didik pada pembelajaran daring biasanya bervariasi, ada yang berupa teleconference untuk guru menyapa muridnya hingga menyampaikan materi dan berupa penugasan yang dapat dikumpulkan pada media e-learning yang digunakan. Kelebihan dari media pembelajaran $e$ learning adalah fleksibel dan dapat diakses dimana saja menggunakan internet, dimana dimasa pandemi COVID-19 memungkinkan segala lapisan masyarakat khususnya guru dengan murid untuk membatasi interaksi sosial antara satu orang dengan yang lainnya. Kekurangan dari media e-learning ini yaitu proses penyampaian ilmu oleh guru kepada muridnya terkadang terganggu, dikarenakan tak menutup kemungkinan beberapa murid tidak dapat menangkap materi secara baik di beberapa media e-learning, baik dikarenakan faktor stimulus ilmu dam tipe belajar peserta yang memiliki keterbatasan antara lain seperti anak yang bertipe audio, visual hinga kinestetik yang berbeda antar satu peserta didik dengan yang lainnya.

Berjalan seiring waktu, e-learning merupakan alasan yang sangat mendasar dalam memanfaatkan Instagram sebagai media pembelajaran online adalah karena memang penggunaannya yang mudah khususnya untuk semua kalangan, tampilan aplikasi yang sangat menarik dan mudah dipahami, dapat dibuka di Smartphone maupun Personal Computer $(P C)$, serta fitur-fitur yang mampu mendukung proses atau kegiatan pembelajaran online. Selain itu, Instagram juga memberikan peluang untuk siswa melakukan eksplorasi membuat produknya sendiri dan diunggah ke Instagram, aktivitas belajar sepanjang hayat, dan kolaborasi pendidik dengan peserta didik dalam hal belajar mengajar (Bexbeti, 2014).

Secara Khusus, Instagram memiliki beberapa fitur-fitur yang dapat menunjang pembelajaran daring antara lain Live Streaming yang sama halnya seperti teleconference yang memudahkan interaksi guru dalam monitoring segala kebutuhan materi belajar siswa. Juga fitur Post Feed yang memungkinkan murid dapat menggumpulkan tugas ataupun karya yang 
nantinya dikirim melalui Instagram dalam bentuk Posting. Hingga Instagram TV yang memudahkan siswa dalam mengumpulkan tugas dan karya berupa video ataupun animasi terkait pembelajaran dengan durasi maksimal 30 menit dan minimal 1 menit. Media Sosial Instagram juga memiliki fitur absensi yaitu dengan mengikuti (follow) akun guru terlebih dahulu dan setelah itu absensi dapat dilanjutkan dalam bentuk tatap muka melalui fitur live streaming. Dengan mengadaptasi Aplikasi Instagram sebagai aplikasi media pembelajaran daring. Guru dapat dengan mudah melihat perkembangan belajar siswa dengan lebih ringkas dan kekinian, dikarenakan Aplikasi Instagram yang perkembangannya banyak digandrungi siswa dalam mengabadikan momen dan foto dalam bentuk postingan.

Dari pemaparan pada uraian diatas, dapat dirumuskan permasalahan, yaitu (1) Bagaimana pemahaman siswa mengenai Instagram yang dapat digunakan sebagai media pembelajaran online? (2) Bagaimana pemahaman siswa dalam menggunakan Instagram sebagai media pembelajaran oline? (3) Bagaimana pemahaman siswa mengenai penggunaan Instagram sebagai forum diskusi dalam pembelajaran online? (4) Bagaimana pemahaman siswa dalam penggunaan Instagram sebagai interaksi dengan guru dalam pembelajaran online? (5) Bagaimana pemahaman siswa dalam penggunaan fitur live streaming di Instagram dalam pembelajaran online? (6) Bagaimana pemahaman siswa mengenai penggunaan fitur post feed di Instagram untuk mengumpulkan tugas dalam pembelajaran online?

Penelitian ini bertujuan untuk menganalisis fitur-fitur yang ada di aplikasi media sosial Instagram dalam mendukung proses pembelajaran secara daring atau online dalam pelajaran biologi serta pemahaman siswa dalam penggunaannya.

\section{METODE}

Penelitian ini dilaksanakan pada 28-30 Mei 2020. Tujuan dari penelitian ini untuk menganalisis ketersampaian materi pelajaran Biologi kelas X SMA pada bab virus dengan menggunakan media sosial Instagram. Instagram merupakan aplikasi media sosial yang diminati khalayak umum dikarenakan pengoperasiannya yang User Friendly dan mudah diakses. dalam pemanfaatannya, mayoritas pengguna Instagram menggunakan Instagram untuk membagikan cerita dan foto.

Penelitian ini merupakan analisis deskriptif dengan bentuk penelitian mix methode dalam menganalisis fitur-fitur pada Instagram yang menunjang terhadap pembelajaran online biologi pada bab virus. Rentang data yang dikumpulkan yaitu dari siswa dan siswi SMA melalui google formulir. Sebelum mengisi kuesioner, responden mencoba beberapa fitur Instagram yang telah disediakan oleh peneliti seperti Instagram TV, dan Post Feed. Setelah itu pa- 
ra responden mengisi kuesioner.

Data yang telah terkumpul adalah data kuesioner dari responden dengan menggunakan Skala Likert 1-5 terkait tanggapan mengenai fitur pembelajaran online dengan bantuan media sosial Instagram. Dari data tersebut peneliti dapat menghimpun dan menganalisis data dengan kesesuaian fitur-fitur Instagram yang telah disediakan dan dilihat oleh responden sebelumnya.

\section{HASIL}

Pada penelitian ini, telah dilakukan kepada 10 orang peserta didik tingkat SMA di Kota Jember yang dipilih secara acak melalui kuesioner Google Form. Hasil penelitian dipaparkan dalam beberapa sub bagian dengan indeks atau persentase dari hasil perhitungan Skala Likert, yaitu sebagai berikut:

1. Mengetahui bahwa Instagram dapat digunakan sebagai media pembelajaran online

Dari hasil pengisian kuesioner oleh responden, indeks yang diperoleh adalah sebesar $80 \%$ (sangat setuju).

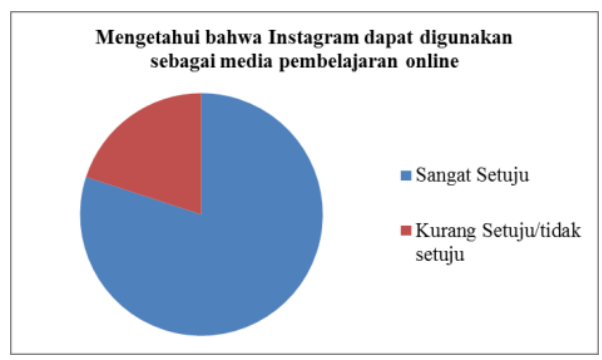

\section{Gambar 1. Grafik perbandingan pengetahuan peserta didik mengenai Instagram sebagai media pembelajaran online.}

2. Sering menggunakan Instagram sebagai media pembelajaran oline

Dari hasil pengisian kuesioner oleh responden, indeks yang diperoleh adalah sebesar $68 \%$ (setuju).

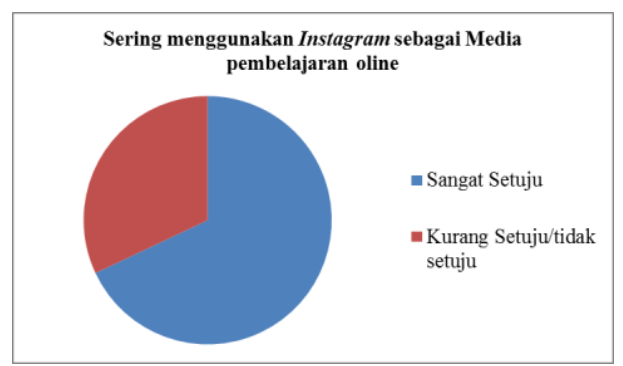

Gambar 2. Grafik perbandingan keseringan peserta didik menggunakan Instagram sebagai media pembelajaran online.

3. Pernah menggunakan Instagram sebagai forum diskusi dalam pembelajaran online 
Dari hasil pengisian kuesioner oleh responden, indeks yang diperoleh adalah sebesar $60 \%$ (setuju).

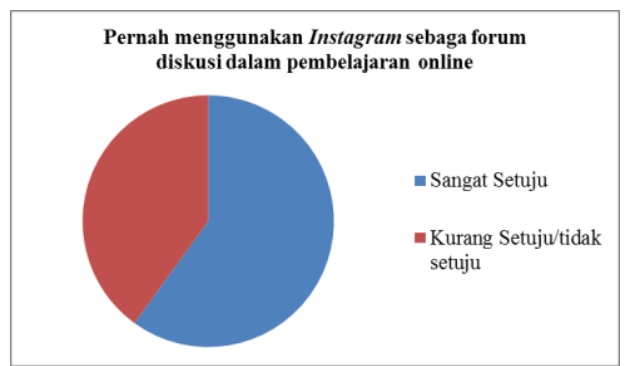

Gambar 3. Grafik perbandingan pernah tidaknya peserta didik dalam menggunakan Instagram sebagai forum diskusi media pembelajaran online.

4. Pernah menggunakan Instagram sebagai interaksi dengan guru dalam pembelajaran online

Dari hasil pengisian kuesioner oleh responden, indeks yang diperoleh adalah sebesar $54 \%$ (pernah).

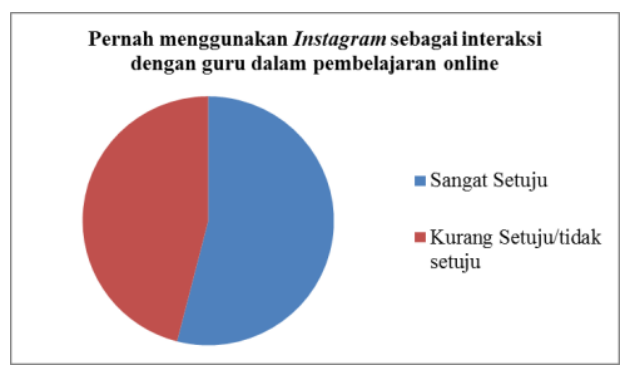

Gambar 4. Grafik perbandingan pernah tidaknya peserta didik dalam menggunakan Instagram sebagai interaksi dengan guru dalam pembelajaran online.

5. Pernah menggunakan fitur live streaming di Instagram dalam pembelajaran online

Dari hasil pengisian kuesioner oleh responden, indeks yang diperoleh adalah sebesar $58 \%$ (pernah).

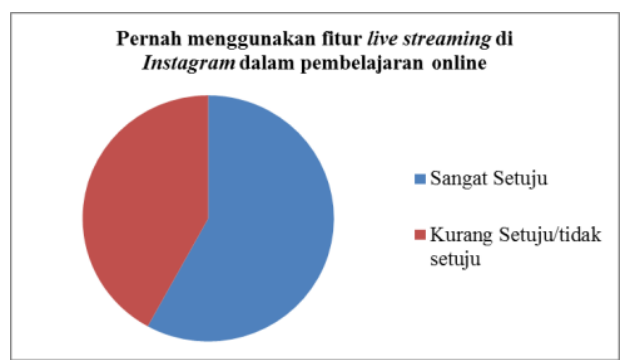

Gambar 5. Grafik perbandingan pernah tidaknya peserta didik dalam menggunakan fitur live streaming di Instagram dalam pembelajaran online.

6. Pernah menggunakan fitur post feed di Instagram untuk mengumpulkan tugas dalam 
pembelajaran online

Dari hasil pengisian kuesioner oleh responden, indeks yang diperoleh adalah sebesar $58 \%$ (pernah).

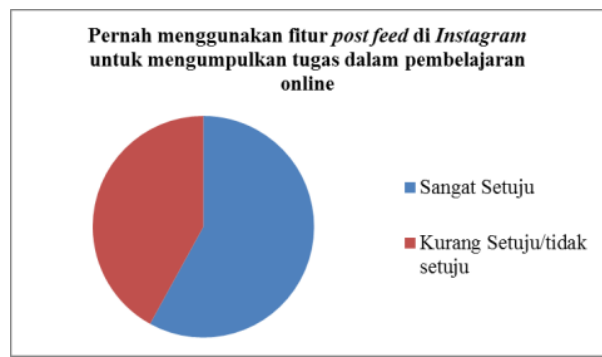

\section{Gambar 6. Grafik perbandingan pernah tidaknya peserta didik dalam menggunakan fitur post feed di Instagram untuk mengumpulkan tugas dalam pembelaja ran online.}

\section{PEMBAHASAN}

Instagram sangat menarik dengan fitur-fiturnya untuk mendukung kebutuhan komunikasi. Apalagi Instagram dan fitur pendukungnya juga dapat digunakan sebagai media dalam kegiatan terkait proses pembelajaran. Peneliti menggunakan Instagram sebagai media pada mata pelajaran biologi dengan materi virus sebagai bahan uji coba yang diberikan pada siswa sekolah menengah atas jurusan ipa. Pada penelitian ini peneliti memfokuskan pada tiga fitur yang terdapat didalam Instagram yakni feed post, Intagram tv, dan Instagram live.

Pembelajaran menggunakan media aplikasi Instagram sangat mudah diterapkan di kalangan siswa SMA karena aplikasi ini sangat familiar dikalangan generasi milenial. berbeda halnya dengan aplikasi pembelajaran seperti google classroom dan edmodo selain itu Instagram tidak memakan banyak kuota karena beberapa provider telekomunikasi menawarkan paket unlimited Instagram yang sering juga dibeli oleh siswa, sehingga siswa dapat dengan mudah mempelajari matapelajaran virus dikarenakan pengoperasian Instagram sangat user friendly.

Dari hasil pengisian kuesioner skala Likert oleh responden, peneliti menemukan bahwa berdasarkan indeks hasil perhitungan data, sebanyak $80 \%$ siswa mengetahui bahwa Instagram dapat digunakan sebagai media pembelajaran online. Hal tersebut karena Instagram sendiri memang sudah umum bagi banyak kalangan siswa. Selain itu Instagram juga mudah dalam pengoperasiannya serta tampilannya yang menarik dengan berbagai konten maupun fitur, sehingga siswa dengan mudah menyadari bahwa Instagram dapat digunakan sebagai media pembelajaran Online. Dari beberapa hal tersebut, merupakan keunggulan Instagram sebagai 
media sosial yang dengan mudah untuk konteks pendidikan sosial dan promosi pemikiran kritis peserta didik (Mason, 2006).

Kemudian pada aspek keseringan dalam menggunakan Instagram sebagai media pembelajaran online, indeks penelitian menunjukkan $68 \%$ setuju bahwa mereka pernah menggunakan Instagram sebagai media pembelajaran online. Kesempatan tersebut memanglah secara tidak langsung dilakukan oleh siswa, dimana banyak dari konten Instagram dari berbagai akun (formal maupun nonformal) yang mengunggah konten atau postingan mengenai hal-hal yang berbau edukasi.

Pada aspek pernah atau tidaknya siswa menggunakan Instagram sebagai forum diskusi dalam pembelajaran online, indeks penelitian menunjukkan $60 \%$ siswa setuju dan pernah melakukan diskusi dalam pembelajaran online menggunakan Instagram. Hal tersebut diperkuat dengan pendapat Spencer (2012) bahwa ada berbagai aktivitas guru maupun siswa yang dapat diimplementasikan di kelas Online Instagram mereka, yakni memanfaatkan presentasi digital, berlatih tata bahasa pada keterangan foto, mengambil untuk foto jurnalistik, membuat foto pribadi, menemukan metafora dalam foto yang dipilih, membuat foto blog, menemukan dan mendokumentasikan konteks dalam foto, melakukan studi etnografi, berbagi seni, dan melatih ekspresi kreatif dan artistik melalui pengambilan gambar sendiri. Mereka juga dapat saling bertukar pendapat dan saling berkomentar secara teratur.

Sementara itu, pada aspek pernah atau tidaknya siswa dalam menggunakan Instagram sebagai interaksi dengan guru dalam pembelajaran online, sebanyak 54\% siswa pernah melakukan interaksi dengan guru selama pembelajaran online menggunakan Instagram. Hal tersebut merupakan salah satu dari beberapa keunggulan Instagram sebagai aplikasi sosial media yang dapat dimanfaatkan oleh guru secara aktif untuk tetap berhubungan dengan siswa atau untuk mengatur kegiatan online dalam pembelajaran online (Zhang, 2013).

Pada aspek pernah atau tidaknya siswa dalam menggunakan fitur live streaming di Instagram dalam pembelajaran online, sebanyak 58\% siswa pernah mengunakan fitur live streaming di Instagram dalam pembelajaran online. Demikian juga pada aspek pernah atau tidaknya siswa dalam menggunakan fitur post feed di Instagram untuk mengumpulkan tugas dalam pembelajaran online, sebanyak 58\% siswa pernah melakukan kegiatan tersebut (menggunakan fitur post feed di Instagram untuk mengumpulkan tugas dalam pembelajaran online). Tugas yang dimaksud adalah postingan dalam bentuk video maupun foto hasil kerja siswa maupun yang sudah ada di album kamera pengguna/siswa. Dari postingan tersebut, pengguna atau siswa dapat menambahkan caption atau keterangan yang menjelaskan foto ataupun video yang sudah diupload (Lodya \& Nur, 2019). 


\section{KESIMPULAN DAN SARAN}

\section{Kesimpulan}

Berdasarkan penelitan yang dilakukan peneliti dan hasil dari kuesioner aplikasi Instagram sangat cocok dijadikan media pembelajaran biologi secara online atau daring hal ini dikarenakan aplikasi Instagram sangat mudah untuk digunakan dan merupakan aplikasi yang familiar dikalangan generasi milenial terutama siswa sekolah menengah atas. Beberapa fitur dalam aplikasi Instagram juga sangat mendukung proses pembelajaran diantaranya adalah feed post yang berguna untuk memberikan gambaran awal tentang materi yang hendak disampaikan kemudian intagram tv yang berguna untuk guru supaya dapat menjelaskan atau menerangkan materi yang hendak disampaikan dan Instagram live yang berguna untuk proses tanya jawab seputar materi pembelajaran yang disampaikan sehingga siswa dan guru dapat berinteraksi serta melalui fitur live Instagram guru juga dapat mengabsen siswanya.

\section{Saran}

Seiring berkembangnya kemajuan teknologi utamanya dalam dunia pendidikan. Inovasi dalam bidang penelitian pendidikan perlu perhatian khusus untuk memberikan stimulus baru terhadap setiap lini pendidikan pada masa mendatang. Dengan adanya penelitian ini diharapkan perlu adanya penelitian lanjutan mengenai artikel ini. Untuk para peneliti lain diharapkan mengembangkan penelitian ini untuk memperbarui baik secara teknis dalam keberlangsungan inovasi-inovasi selanjutnya. Serta perlu adanya kreativitas seorang pendidik dalam menggunakan Instagram ataupun e-learning sejenisnya sebagai media pembelajaran online.

\section{DAFTAR RUJUKAN}

Arsyad, Azhar. 1997. Media Pengajaran Jakarta:Raja Grafindo Persada.

Bexheti, Lejla A, Burim E. Ismaili, and Betim H. Cico. "An Analysis of Social Media Usage in Teaching and Learning: The Case of SEEU." Proceedings of the International Conference on Circuits, Systems, Signal Processing, Communications and Computer (2014): 90-94.

Mason, R. "Learning Technologies for adult Continuing Education." Studies incontinuing Education 28.2 (2006): 121-133.

Sesriyani, Lodya dan Najibah, Nur. "Analisis Penggunaan Instagram Sebagai Media Pembelajaran Bahasa Inggris pada Program Studi Pendidikan Ekonomi." EDUKA Jurnal Pendidikan, Hukum dan Bisnis, no. 1 (2019), 2505-5406. 
Spencer, J. Ten ideas for using Instagram in the classroom. 2012. http://www.educationrethink.com/2012/07/ten-ideasfor-using-Instagram-in.html [12 March. 2016]

Hamalik, Oemar. 1989. Media Pendidikan Bandung : Citra Aditya.

Nasution, 2008. Teknologi Pendidikan. Jakarta: Bumi Aksara.

Zhang, Lili. "Mobile phone teachnology engageent in EFL classroom." International Conference on Software and Computer Science (ICSECS) (2013): 171-17. 